\title{
Effect of medium composition, genotype and age of explant on the regeneration of hexaploid plants from endosperm culture of tetraploid kiwiberry (Actinidia arguta)
}

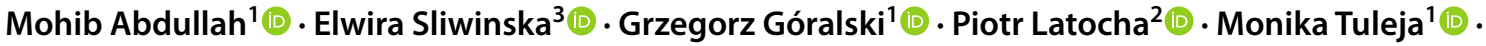 \\ Patrycja Widyna ${ }^{1}$ (D) Marzena Popielarska-Konieczna ${ }^{1}$ (D)
}

Received: 4 May 2021 / Accepted: 30 July 2021 / Published online: 18 August 2021

(c) The Author(s) 2021

\begin{abstract}
Endosperm, an ephemeral and storage tissue, serves as a source of nutrition and protection during embryo development and germination. It can be used for the cultivation of polyploid plants in vitro. Here, results of plant regeneration and acclimatization from the endosperm-derived calli of four cultivars of Actinidia arguta has been presented. Seeds excised from fresh fruit and dry seeds stored for one year served as the sources of endosperm explants of selected tetraploid cultivars of $A$. arguta. Callus Induction Medium (CIM; containing 0.25, 0.5, or $1 \mathrm{mg} / \mathrm{l}$ of TDZ) and Actinidia Endosperm Medium (AEM; containing $2 \mathrm{mg} / \mathrm{l}$ of 2,4-D and $5 \mathrm{mg} / \mathrm{l}$ of kinetin) were used to study the organogenic responses of the calli. On AEM, the source of explant did not significantly affect the rate of callus induction for any of the tested cultivars; no organogenic events were observed. In contrast, on CIM both the source of explants and the cultivar origin caused significant differences in callus formation and subsequent organogenic events. Histological and ultrastructural analyses revealed the adventitious nature of shoot bud formation on these media. The most efficient elongation of shoot buds was achieved after transferring organogenic calli with adventitious shoot buds to a medium supplemented with zeatin or meta-topolin. Robust root induction with minimal basal callus formation occurred on the medium with indole-3-acetic acid. Flow cytometric analysis revealed that the nuclear DNA content in the leaves of some regenerants was approximately $50 \%$ higher $(4.5 \mathrm{pg} / 2 \mathrm{C})$ than that in leaves from the tetraploid seedlings $(3.1 \mathrm{pg} / 2 \mathrm{C})$, which confirmed that those regenerants originated from the endosperm. The regeneration of such hexaploid plants was more efficient when endosperm from fresh seeds served as an explant; therefore, fresh rather than dry seeds are recommended for endosperm-derived plant production. The hexaploid plants of $A$. arguta can serve as an important source of breeding material.
\end{abstract}

\section{Key message}

This study reveals that the genotype, thidiazuron, zeatine, meta-topolin, and age of explants affect the induction of endospermderived callus and subsequent hexaploid plant regeneration from tetraploid kiwiberry.

Keywords Callus $\cdot$ Flow cytometry $\cdot$ Histology $\cdot$ Meta-topolin $\cdot$ Ultrastructure $\cdot$ Zeatin

Communicated by Ranjith Pathirana.

Mohib Abdullah

mohib.abdullah@doctoral.uj.edu.pl

1 Department of Plant Cytology and Embryology, Faculty of Biology, Institute of Botany, The Jagiellonian University in Cracow, Gronostajowa 9, 30-387 Cracow, Poland

2 Department of Environmental Protection and Dendrology, Faculty of Horticulture and Biotechnology, Institute of Horticulture Sciences, Warsaw University of Life Sciences - SGGW, Nowoursynowska 159, 02-776 Warsaw, Poland

3 Department of Agricultural Biotechnology, Faculty of Agriculture and Biotechnology, UTP University of Science and Technology in Bydgoszcz, Kaliskiego Ave. 7, 85-789 Bydgoszcz, Poland 


\section{Introduction}

Due to their origin, endosperm cells usually possess a higher nuclear DNA content (3C) than the embryo (2C), which results from the doubled fertilization that occurs in flowering plants. Additionally, endosperm plays a very important role during seed development and germination, acting as a vital repository of nutrients for the developing and germinating embryo (Kumar and Gupta 2015). The relationship between ploidy level and some fruit characteristics (e.g., fruit weight or flesh color) is crucial for the breeding and trade of kiwifruit ( $\mathrm{Li}$ et al. 2010; Wu et al. 2012). To obtain polyploid plants via conventional methods, long and labor-intensive procedures are usually required. Plant tissue culture techniques can provide a relatively faster alternative for obtaining polyploid plants (Wang et al. 2016). One of such technique is culturing of isolated endosperm followed by plant regeneration. To date, nearly 70 species have been cultured under in vitro conditions using endosperm cultures. However, the ability of isolated endosperm to proliferate and for plants to regenerate has been found for fewer than 40 of the species (Hoshino et al. 2011; Wang et al. 2016). Furthermore, the plant growth regulators (PGRs) added to the culture medium, the sources of the explant material, and the cultivar of the donor plants all play an important role in establishing a successful regeneration protocol from endosperm explants (Wang et al. 2016). Despite being challenging task, the recently published protocols for endosperm-derived plant regeneration in Gomortega keule (Muñoz-Concha 2016), Melia azedazach (Thang et al. 2018), Passiflora edulis (Antoniazzi et al. 2018), and Passiflora cincinnata (Silva et al. 2020) indicate that this technique is still attracting interest and is worth applying to economically important plant species.

The native distribution range of the genus Actinidia (with 54 species and more than 100 taxa) is Asia, especially southwestern China (Ferguson and Huang, 2007; Ferguson 2016; Huang 2016). Most of these species, however, are cold-sensitive. Only selected species, such as Actinida arguta (Siebold et Zucc.) Planch. ex Miq., known as kiwiberry or sometimes as "cold-hardy kiwifruit" or "mini-kiwi," can be cultivated in regions where temperatures can fall even below $-30^{\circ} \mathrm{C}$ (Debersaques et al. 2015). In addition to cold resistance, this species possess such advantageous characteristics as grape-sized, hairless fruits, which at harvest stage are delicate, aromatic, and rich in vitamin C, carotenoids, and polyphenols (Latocha 2017). On the global fresh fruit market, the kiwiberry is less common than the more popular "fuzzy" kiwifruit, A. chinensis var. deliciosa (Cossio et al. 2015; Melo et al. 2017). However, a positive trend has been noticed towards the establishment of new kiwiberry plantations in countries such as Poland, Belgium, and the Netherlands because more and more people are becoming aware of the health benefits associated with kiwiberry consumption (Debersaques et al. 2015).

In the genus Actinidia, successful plant regeneration through cultured endosperm has been reported for $A$. chinensis (Gui et al. 1982), the hybrids A. chinensis $\times A$. melanandra and A. arguta $\times$ A. deliciosa (Mu et al. 1990), Actinidia ssp. (Machno and Przywara 1997), A. chinensis var. deliciosa (Góralski et al. 2005; Chłosta et al. 2021), and A. kolomikta (Asakura and Hoshino 2017). However, Machno and Przywara (1997) found that during the culturing of endosperm-derived callus of $A$. arguta (the name of the cultivar not provided), only roots and a few abnormal shoots were formed and no normal regenerants suitable for further breeding developed.

The aim of the present study was to develop a protocol for plant regeneration from the isolated endosperm tissue of selected cultivars of A. arguta. An experimental system established previously for plant regeneration from endosperm tissue in A. chinensis var. deliciosa (Góralski et al. 2005) turned out to be somewhat appropriate for $A$. arguta. Since numerous previous studies have demonstrated that the cultivars can differ in the regeneration capacity, four cultivars were tested. Additionally, the study investigated whether the source of the material (seeds excised from fresh fruit or from dry seeds stored for one year) influences proliferation and regeneration potential. The results increase the knowledge of additional plant species with the ability to proliferate in vitro through endosperm and to regenerate plants possessing $3 \mathrm{C}$ nuclear DNA content and contribution of a double maternal DNA.

\section{Materials and methods}

\section{Plant materials}

Vines of kiwiberry (A. arguta) were selected from the plant germplasm collection at Warsaw University of Life Sciences (SGGW), located in Warsaw, Poland. Four female cultivars were used in the current study: 'Geneva,' of American origin, 'Weiki,' of German origin, and two Polish cultivars, 'Scarlet September Kiwi' ${ }^{\circledR}$ and 'Bingo' ${ }^{\text {PBR }}$. They all are tetraploids with a chromosome number of $2 \mathrm{n}=4 x=116$ (Melo et al. 2017). The plants were exposed to open pollination and mature (soft, ready-to-eat) fruits were collected at the end of September in 2018 and 2019. For 'Geneva' and 'Scarlet September Kiwi' it was 100 and 105 days after petal fall (DAPF), for 'Bingo' 105 and 110 DAPF, and for 'Weiki' 110 and 115, in 2018 and 2019, respectively. The harvested fruits were divided into two lots. One lot was placed in 
small, breathable plastic boxes immediately after collecting and was stored at $10^{\circ} \mathrm{C}$ in a refrigerator, to be used as the endosperm source for the fresh material (fresh seeds). From the second lot, the pulp and seeds were taken out, washed first in tap water and then in distilled water, dried at room temperature for a few hours, and then stored for one year at room temperature in a glass jar; they were used as the endosperm source for the dry material (dried seeds). The fruits were sterilized, the seeds dissected from the fruit, the seed coats excised, the embryos isolated, and the endosperm tissue dissected (Fig. 1a), according to a protocol previously developed for A. chinensis var. deliciosa (Góralski et al. 2005). Dry seeds after sterilization were soaked in distilled, sterile water for $24 \mathrm{~h}$ at room temperature before endosperm isolation.

\section{Callus induction}

The endosperms isolated from fresh seeds and from the oneyear-old dry seeds were inoculated on $60-\mathrm{mm}$ Petri dishes with a culture medium based on the Murashige and Skoog (1962) (MS) macro-, microelements, and vitamins (Duchefa), supplemented with $3 \%$ sucrose, $0.6 \%$ agar (Duchefa) and PGRs. For the callus induction medium (CIM), the medium described above was supplemented with 0.25 (CIM-0.25), 0.5 (CIM-0.5), or $1.0 \mathrm{mg} / \mathrm{l}$ (CIM-1.0) of thidiazuron (TDZ), and Actinidia Endosperm Medium (AEM) with $2 \mathrm{mg} / \mathrm{l}$ of 2,4-dichlorophenoxy-acetic acid (2,4-D) and $5 \mathrm{mg} / \mathrm{l}$ of kinetin (KIN). CIM without any PGRs (CIM-0) was used as a control medium. Sealed with Parafilm ${ }^{\circledR}$ Petri dishes with endosperm explants were incubated at $25{ }^{\circ} \mathrm{C}$ in the dark. The proliferating explants were transferred to fresh medium every three weeks and incubated under the same conditions.

Observations and the capture of images were performed using a dissecting binocular microscope (Zeiss Stemi SV 11, Germany) that was equipped with a digital camera (Canon Power Shot G6). The captured images were processed with CorelDRAW Graphics Suite 2020 software.

\section{Shoot bud development}

Calli with visible (with a height of approx. $5 \mathrm{~mm}$ ) adventitious shoot primordia were transferred to $90 \times 25 \mathrm{~mm}$ (diameter $\times$ height) Petri dishes (Phoenix Biomedical) containing six types of Shoot Development Medium (SDM). All SDMs contained full-strength MS salts and vitamins (Duchefa), 3\% sucrose, and $0.6 \%$ agar (Duchefa). SDM0 did not contain any PGRs, while SDM1 was supplemented with $0.5 \mathrm{mg} / \mathrm{l}$ of TDZ, SDM2 with $2 \mathrm{mg} / \mathrm{l}$ of 6-Benzylaminopurine, SDM3 with $2 \mathrm{mg} / \mathrm{l}$ of KIN, SDM4 with $2 \mathrm{mg} / \mathrm{l}$ of meta-topolin $(m \mathrm{~T})$, and SDM5 with $2 \mathrm{mg} / \mathrm{l}$ of zeatin (ZEA). All cultures were incubated at $25{ }^{\circ} \mathrm{C}$ with a 16 -h photoperiod under
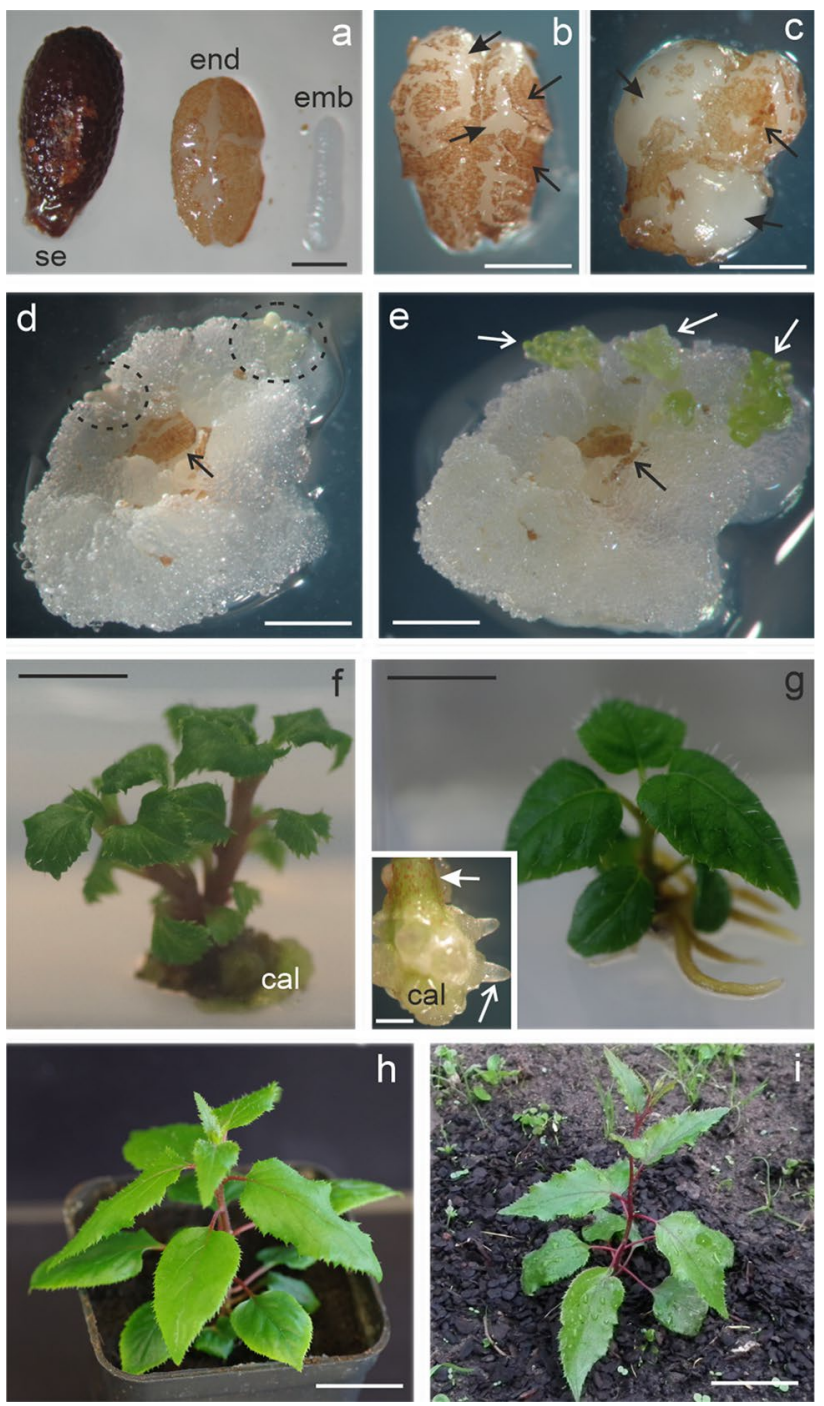

Fig. 1 Callus induction and plant regeneration from cultured endosperm of Actinidia arguta 'Bingo' a whole seed (se), endosperm (end) after removing seed coat and dissecting embryo (emb). Callus proliferation (black arrows) after seven (b) and ten (c) days of culturing on $0.5 \mathrm{mg} / \mathrm{TDZ}$; visible remnants of seed coat (open black arrows). Callus with shoot primordia (dotted line) (d) and shoot buds (white open arrows) (e), after four and six weeks of culturing, respectively. f Shoots with callus ( $\mathrm{cal}$ ) on the basal end of the stem on $2 \mathrm{mg} / \mathrm{l}$ ZEA. g Rooted plant on $0.2 \mathrm{mg} / \mathrm{l} \mathrm{IAA}$; magnification of a basal end of stem (white arrow) with callus and root induction (open white arrow) in inset. Plant acclimatized in a pot (h) and in soil in a garden (i). Scale bars $=200 \mu \mathrm{m}(\mathbf{a}) ; 500 \mu \mathrm{m}(\mathbf{b}, \mathbf{c}) ; 1 \mathrm{~mm}(\mathbf{d}, \mathbf{e}) ; 1 \mathrm{~cm}$ (f, g); $1 \mathrm{~mm}(\mathbf{g}$ inset); $2 \mathrm{~cm}(\mathbf{h}, \mathbf{i})$

cool-white fluorescent tubes $\left(60-90 \mu \mathrm{mol} \mathrm{m} \mathrm{m}^{-2} \mathrm{~s}^{-1}\right)$ for 60 days.

\section{Rooting and acclimatization}

Regenerated shoots with the height of approx. $2-3 \mathrm{~cm}$ were excised from the callus clumps. Micro-cuttings were 
sub-cultured in Magenta ${ }^{\mathrm{TM}}$ vessels (Sigma) with four types of Root Induction Media (RIM). All RIMs were provided with half-strength MS salts and vitamins (Duchefa), 2\% sucrose, and $0.6 \%$ agar (Duchefa). RIM0 did not contain any PGRs, while RIM1 was supplemented with $0.2 \mathrm{mg} / \mathrm{l}$ of indole-3-acetic acid (IAA), RIM2 with $0.2 \mathrm{mg} / \mathrm{l}$ of indole3-butyric acid (IBA), and RIM3 with $0.2 \mathrm{mg} / \mathrm{l}$ of 1-napthaleneacetic acid (NAA). The cultures were kept under the same temperature and photoperiod conditions as described above. Shoots with a well-developed root system were removed from the culture vessels and gently washed in a beaker with sterilized distilled water to wash out the RIM. Afterwards, the plants were placed in small pots with commercial substrate for seeding (Substral Scotts Poland, Warsaw, Poland). The potted plants were watered and covered with a plastic bag to maintain high relative humidity. After two weeks in humid conditions, holes were made in the plastic bags to gradually reduce the humidity. Two months later the shoots were transferred from pots to field conditions in the middle of August 2019. The plants were grown under green netting to protect them from direct sunlight.

\section{Light and scanning electron microscopy}

Six-week-old intact calli with shoot bud domains were collected from CIM-0.5TDZ and fixed overnight at $4{ }^{\circ} \mathrm{C}$ in a solution of $5 \%(\mathrm{v} / \mathrm{v})$ glutaraldehyde in $0.1 \mathrm{M}$ phosphate buffered saline (pH: 7.2). Next, the samples were washed four times in phosphate buffer and dehydrated gradually in an ethanol series, from 10 to $100 \%$ (v/v). The basal stem segments from in vitro rooting shoots with 10-day-old root primordia were excised and fixed as described above. The fixed tissues were embedded in Technovit ${ }^{\circledR} 7100$ synthetic resin and 5- $\mu \mathrm{m}$-thick sections were cut, stained with $0.1 \%(\mathrm{w} / \mathrm{v})$ toluidine blue, and finally mounted in Entellan (Merck, Darmstadt, Germany) according to the procedure described by Popielarska et al. (2006). Observations and documentation were performed using the visible light system of a Nikon Eclipse E400 microscope equipped with a Zeiss AxioCam MRe digital camera and Zeiss AxioVision 3.0 software and a Nikon DS-Fi2 with NIS-Elements 4.0 software.

For scanning electron microscope (SEM) analysis, the fixed samples, after dehydration through a graded ethanol series, were dried with $\mathrm{CO}_{2}$ critical-point drying and coated with gold (Jeol JFC-1100 E ion-sputtering system). Observations were made using a SEM HITACHI S-4700.

\section{Flow cytometry}

Flow cytometric (FCM) analysis was performed on leaf samples from 35 rooted regenerated plants obtained from the endosperm-derived callus of 'Bingo' seeds from both sources of explants, fresh seeds (15 regenerants) and yearold dry seeds (20 regenerants). Leaves from five seedlings grown in vitro and endosperm isolated from fresh seeds (four replicates, endosperm isolated from 15 to 20 seeds per sample) of the tetraploid cultivar 'Bingo' were used as a ploidy control. Samples were prepared as previously described (Sliwinska and Thiem 2007) using nuclei isolation buffer (200 $\mathrm{mM}$ TRIS, $4 \mathrm{mM} \mathrm{MgCl}{ }_{2} \cdot 6 \mathrm{H}_{2} \mathrm{O}, 0.5 \%$ [v/v] Triton X-100; $\mathrm{pH}=7.5)$ supplemented with propidium iodide $(50 \mu \mathrm{g} / \mathrm{mL})$ and ribonuclease A $(50 \mu \mathrm{g} / \mathrm{mL})$. Solanum lycopersicum $(1.96$ $\mathrm{pg} / 2$ C; Doležel et al. 1992) served as an internal standard. The nuclear DNA content was estimated using a CyFlow SL Green (Partec GmbH, Münster, Germany) flow cytometer equipped with a high-grade solid-state laser with green light emission at $532 \mathrm{~nm}$, a long-pass filter RG 590 E, DM 560 A, as well as side and forward scatters. The nuclear DNA content was calculated using the linear relationship between the ratio of the $2 \mathrm{C}$ peak positions of Actinidia/Solanum on a histogram of fluorescence intensities. For each sample, the nuclear DNA content in 5000-8000 nuclei was measured by applying linear amplification. Histograms were evaluated using the FlowMax (Partec GmbH, Münster, Germany) program. The coefficient of variation of the $\mathrm{G}_{0} / \mathrm{G}_{1}$ peak of the Actinidia species ranged from 2.43 to $4.91 \%$.

The $\mathrm{Cx}$ value was calculated based on the genome size of the control tetraploid plants and was applied to establish a DNA ploidy of regenerants. Cx refers to the DNA content of a monoploid genome with the chromosome base number $x$ (Greilhuber et al. 2005). Thus, the abbreviation $4 \mathrm{Cx}$ is used for the $2 \mathrm{C}$ DNA content of a tetraploid plant and $6 \mathrm{Cx}$ for that of a hexaploid. It should be noted that endosperm possess 3C DNA content; therefore, plants originated from endosperm of tetraploid mother plants are hexaploids.

\section{Data recording and statistical analysis}

Statistical analysis was performed with the use of R software v. 3.6 (R Core Team 2020). Confidence intervals (confidence level: 0.95) for proportions were calculated with proportion test [prop.test () function] and the proportions were compared with a use of Fisher's Exact Test for Count Data [fisher.test ()$]$ to examine the effects of the cultivar, the medium, and the source of explant on callus proliferation and shoot bud regeneration; differences were regarded as significant when $p$ was less than 0.05 .

Almost 3000 explants were used for this study of endosperm response (Table 1). For each kind of medium, cultivar, and source of explant, observations were recorded on the proportion of calli and shoot bud induction to establish the efficiency of callus and shoot bud induction. The explants' response was recorded weekly after inoculation.

The experiments were carried out in 1-3 trials and with different numbers of explants. 


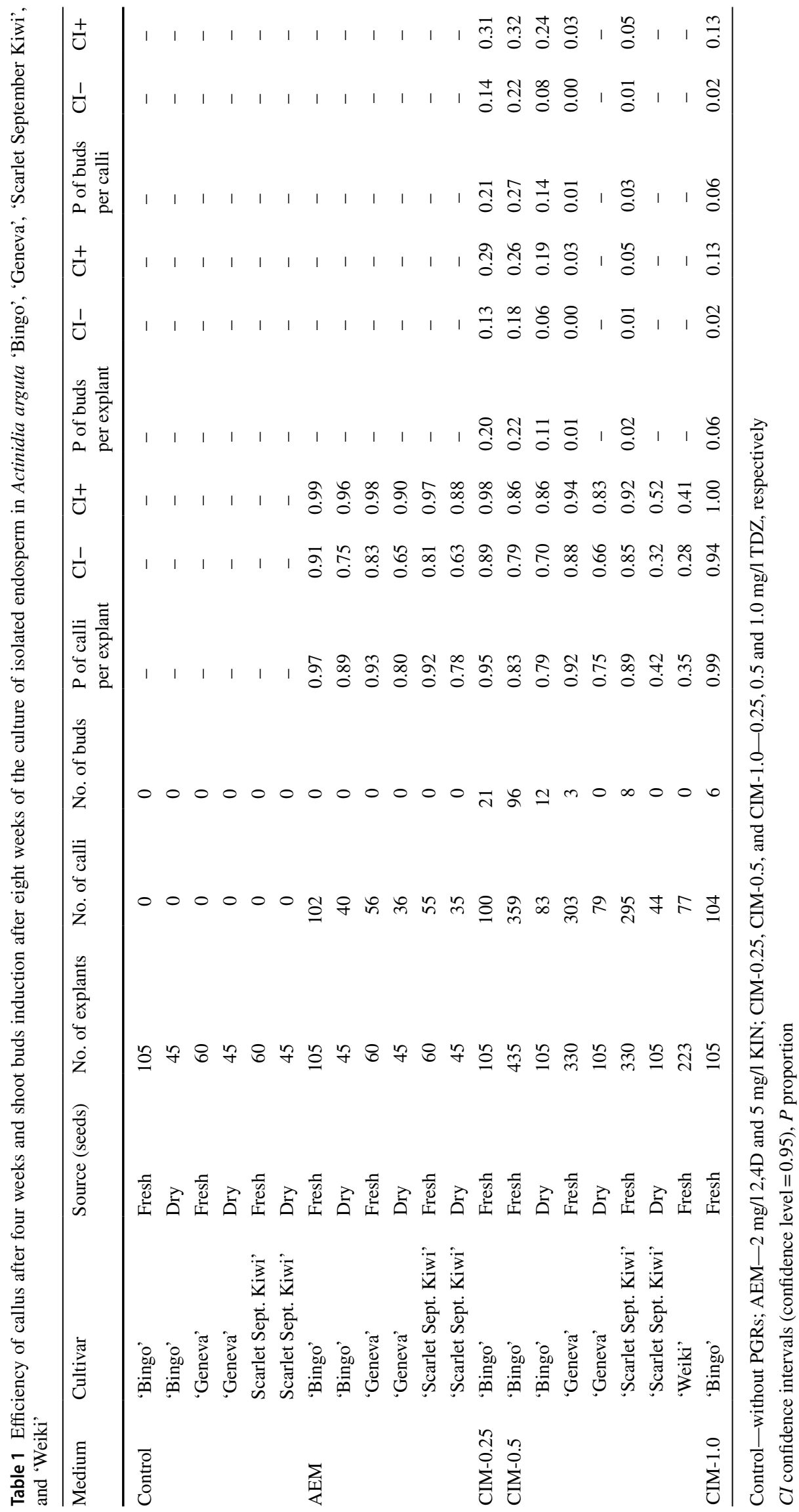




\section{Results}

\section{Callus and shoot bud induction}

Callus induction was observed for all tested cultivars, for both explant sources, and for all tested media (apart from the control one). The first proliferation and enlarging of explants were visible after 7-12 days of culture (Fig. 1b, c). The callus growing on the AEM was soft and aqueous in appearance, while the callus from the CIMs was semi-compact and light-yellow, creamy. During the subsequent days of culturing, the size of the calli cultured on the AEM increased and no organogenic events were observed. Adventitious shoot primordia were visible as light green bulges (Fig. 1d, e). They were observed on all CIMs after about 42 days for 'Bingo' and on CIM- 0.5 after 60 and 80 days for 'Scarlet September Kiwi' and 'Geneva', respectively. Only for 'Weiki' the formation of shoot primordia on CIM-0.5 was not observed.

The source of explant (fresh versus year-old seeds) did not significantly affect callus induction on AEM for any cultivar (Table 1). However, on CIM-0.5 the efficiency of callus formation on the fresh seeds' endosperm was significantly higher for 'Geneva' (the proportions of the number of calli to the number of explants were 0.92 and 0.75 for fresh and oneyear-old seeds, respectively) and 'Scarlet September Kiwi' (0.89 vs. 0.42 ). Explants obtained from fresh 'Weiki' seeds exhibited the lowest efficiency (0.35) of callus formation on CIM-0.5. There were no significant differences in the number of calli induced per explant between cultivars for the same source of explant on AEM, but such differences were found on CIM-0.5. For fresh seeds, more calli developed on 'Geneva' and 'Scarlet September Kiwi' endosperms (0.92 and 0.89, respectively) than on those of 'Bingo' (0.83). Explants derived from one-year-old 'Bingo' and 'Geneva' seeds generated more calli ( 0.79 and 0.75 , respectively) than from 'Scarlet September Kiwi' (0.42).

'Bingo' was the only cultivar for which all media were tested, but only for fresh seeds. The efficiency of callus induction (no. calli/no. explants) was similar among three media - on CIM-1.0 it was 0.99, on AEM 0.97, and on CIM0.250 .95 - and it was significantly higher than on CIM0.5 (0.83). The results for one-year-old seeds were similar, reaching 0.89 and 0.79 on AEM and CIM-0.5, respectively.

The explants of 'Geneva' and 'Scarlet September Kiwi' were tested only on AEM and CIM-0.5. The only significant difference found in callus induction efficiency in a given explant class and cultivar was for explants from oneyear-old 'Scarlet September Kiwi' seeds: on AEM more explants induced calli (0.78) than on CIM-0.5 (0.42).

As mentioned above, buds were formed on calli only when CIMs were used. On CIM-0.5, fresh-seed-derived
'Bingo' explants reached approx. 10- and 20-times higher efficiency of bud formation (0.22; calculated as the number of calli with buds divided by the number of explants) than 'Scarlet September Kiwi' (0.02) and 'Geneva' (0.01). Also, when the proportion of calli with buds to the total number of calli was analyzed, 'Bingo' demonstrated similar superiority. The calli from one-year-old seed endosperm only generated buds in the case of 'Bingo' (0.11), with significantly less efficiency than for fresh seed explants (Table 1).

Because of the 'Bingo' cultivar's high efficiency in bud formation per explant on CIM-0.5, its fresh explants were also tested on other CIMs. The results were similar for CIM0.25 (0.20), but significantly lower for CIM-1.0 (0.06).

\section{Plant regeneration}

The transfer of calli with adventitious shoot buds on SDM1, SDM2, and SDM3 resulted in limited growth of shoots. Initially, the calli turned into compact, green clumps, but during the following weeks all explants with shoot buds became necrotic. Successful shoot elongation was obtained on SDM4 and SDM5 in the case of 'Bingo' and on SDM5 in the case of 'Scarlet September Kiwi' (Fig. 1f). We were only able to test different SDMs for shoot elongation with 'Bingo' because only this cultivar produced a sufficient number of calli clumps with shoot primordia. Due to the limited number of calli with shoot primordia in 'Scarlet September Kiwi' and 'Geneva' from fresh seeds (Table 1), we decided to use SDM5 for shoot elongation in these cultivars, based on our prior promising results with 'Bingo'. However, only for 'Bingo' and 'Scarlet September Kiwi' endospermderived calli with shoot buds obtained on CIM were capable of forming complete shoots when transferred to SDM5 (Fig. 1f; Table 2). During the elongation and development

Table 2 Elongation of shoots obtained from endosperm-derived callus in Actinidia arguta 'Bingo', 'Geneva', and 'Scarlet September Kiwi' after two months of the subculture

\begin{tabular}{llll}
\hline Cultivar & Medium & $\begin{array}{l}\text { No. of calli clumps } \\
\text { with shoot buds }\end{array}$ & $\begin{array}{l}\text { No. of elon- } \\
\text { gated shoots }\end{array}$ \\
\hline 'Bingo' & SDM0 & 15 & 0 \\
& SDM1 & 50 & 0 \\
& SDM2 & 20 & 0 \\
& SDM3 & 20 & 0 \\
& SDM4 & 16 & 42 \\
& SDM5 & 17 & 24 \\
'Scarlet Sept. Kiwi' & SDM5 & 9 & 15 \\
'Geneva' & SDM5 & 3 & 0 \\
\hline
\end{tabular}

SDM0-without PGRs; SDM1-0.5 mg/l TDZ; SDM2-BAP; SDM3-KIN; SDM4- $m$ T; SDM5-ZEA, all at concentration of $2 \mathrm{mg} / \mathrm{l}$ (except TDZ) 
of shoots on SDM4 and SDM5, an intense reddish/pinkish pigment formation was noted in the callus, mostly confined to the region where shoot buds were growing. Shoots 1 to $3 \mathrm{~cm}$ in height were obtained after 60 days of culturing on SDM4 and SDM5 (Fig. 1f). On SDM0, the callus tissue with adventitious shoot buds started turning black after three days of subculturing and ultimately turned completely necrotic after seven days of culturing.

After two months of culturing on SDM4 and SDM5, welldeveloped shoots of 'Bingo' were excised from the growing clumps of the callus (Fig. 1f) and transferred onto different RIMs (Table 3). All treatments resulted in root and callus formation near the basal end of the stem. However, a root system accompanied by a small amount of callus was formed on RIM1 (Fig. 1g) after 30 days of subculturing. Swelling of the basal part of the stem was noted after five days, along with callus induction, followed by a clearly visible formation of the root meristem after ten days of culturing on RIM1 (Fig. 1g, inset). Explants cultured on RIM2 and RIM3 promoted a large basal callus formation at the basal part of the stem. In the case of RIM0 the negligible amount of callus was observed only on the part of stems dipped in a medium. The micro-shoots on the RIM0 overall showed a stunted growth, and produced few, slow-growing roots as compared to the RIMs containing auxins.

\section{Acclimatization}

Fifty plants with a well-developed in vitro root system were acclimatized. During the first week of the acclimatization, the majority of the plantlets started shedding the leaves which had been formed during in vitro culture phase. However, after a few days, swelling of the nodes was observed and healthylooking, green leaves started to grow from the nodes. One month of acclimatization resulted in 25 plants (Fig. 1h) ready to be transferred to field conditions; the survival rate was $50 \%$.

Table 3 Root induction of micro-cuttings shoots in Actinidia arguta 'Bingo', and 'Scarlet September Kiwi' after one month of the subculture

\begin{tabular}{llll}
\hline Cultivar & Medium & $\begin{array}{l}\text { No. of shoots } \\
\text { cultured }\end{array}$ & $\begin{array}{l}\text { No. of shoots } \\
\text { forming roots }\end{array}$ \\
\hline 'Bingo' & RIM0 & 6 & 6 \\
& RIM1 & 6 & 6 \\
& RIM2 & 6 & 6 \\
& RIM3 & 6 & 6 \\
'Scarlet Sept. Kiwi' & RIM0 & 3 & 3 \\
& RIM1 & 4 & 4 \\
& RIM2 & 4 & 4 \\
& RIM3 & 4 & 4 \\
\hline
\end{tabular}

RIM0—without PGRs; RIM1-IAA; RIM2-IBA; RIM3-NAA, all at concentration of $0.2 \mathrm{mg} / \mathrm{l}$
Fully acclimatized regenerated plants (Fig. 1i) were obtained within six months of the endosperm being isolated, which confirms the efficacy of the protocol.

\section{Ultrastructural and histological analyses}

The ultrastructural and histological analyses of the endosperm explants (Fig. 2a-b1) and six-week-old calli cultured on CIM0.5 (Fig. 2c, d) were performed using an SEM and a light microscope. Sections of freshly isolated endosperm revealed thick-walled cells with abundant storage substances (Fig. 2a, a1). On sections of endosperm explants after 14 days of culturing, post-division cells without storage substances were detected (Fig. 2b, b1). Histological sections of six-week-old cultures revealed the formation of multiple shoot bud domains (Fig. 2c). These structures were composed of cells with uniform size and shape and dense cytoplasm, covered with an epidermal-like layer, and maintaining continuity with callus. The formation of shoot buds was also noted using SEM (Fig. 2d); callus domains were surrounded by small, irregular clumps of parenchymatic cells. Cross-sections of stem from the micro-cutting, cultured for 10 days on RIM1, showed little induction of basal callus and lateral root primordia (Fig. 2e). The vascular connection between the xylem of the main stem and the developing root was clearly visible.

\section{Nuclear DNA content and DNA-ploidy}

The 2C nuclear DNA content in the leaves of control tetraploid plants of 'Bingo' was $3.15 \mathrm{pg}$, and the 3C nuclear DNA content in the endosperms isolated from 'Bingo' seeds was 4.75 pg (Fig. 3; Table 4). Twenty-five regenerated plants, regardless of the source explant (fresh or dry seeds), formed two distinct groups with clearly different genome sizes, one with about $3.1-3.2 \mathrm{pg} / 2 \mathrm{C}$ and the other with $4.5 \mathrm{pg} / 2 \mathrm{C}$ of DNA. Since the latter one (17 regenerants) possessed approx. 1.5 times the amount of DNA of the tetraploid control, they were considered to be hexaploids $(6 \mathrm{Cx})$ of endosperm origin. The remaining regenerants possessed DNA content similar to the control, so their DNA-ploidy was estimated as tetraploid (4Cx). The frequency of hexaploid regenerants differed depending on the explant source: when endosperm was isolated from fresh seeds, 14 per plantlets were $6 \mathrm{Cx}$, while this proportion among regenerants obtained from the dry seeds decreased to 3 per 20 . The monoploid genome size (1Cx) for tetraploids was about $0.79 \mathrm{pg}$ and for hexaploids $0.75 \mathrm{pg}$. 

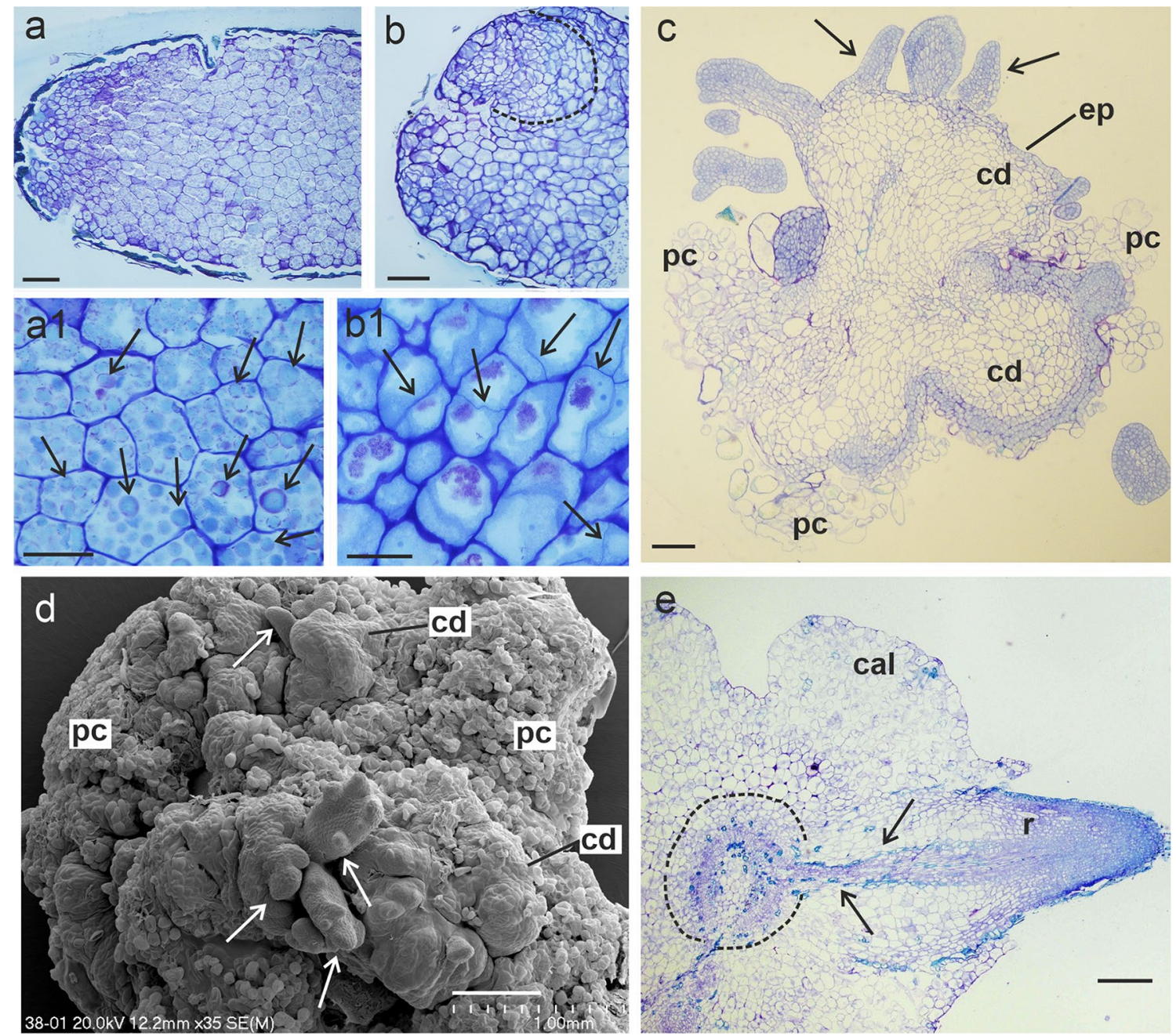

Fig. 2 Histological (a-c, e) and ultrastructural (d) analyses of proliferation and regeneration from endosperm-derived callus in Actinidia arguta 'Bingo'. a Freshly isolated endosperm; magnification a1 revealed cells abundant in storage materials (arrows). b Explant after 14 days of culturing on $0.5 \mathrm{mg} / \mathrm{l} \mathrm{TDZ}$; notice the induction of a callus (dashed line); magnification b1 revealed vacuolated cells after division (arrows). c, d Adventitious shoot buds (arrows) arising from

\section{Discussion}

\section{Callus induction and plant regeneration}

Endosperm tissue was previously successfully used for the in vitro regeneration of species in the genus Actinidia (Hoshino et al. 2011). In that study, the endosperm was isolated only from seeds obtained from fresh fruits. The current work is the continuation of studies on isolated endosperm of A. arguta 'Bingo' (Popielarska-Konieczna et al. 2020), which revealed that cultured explants displayed structural and chemical differences in the cell wall depending on the type of morphogenic pathway. In the present study, we focused on culture medium composition - especially PGRs the callus domains $(c d)$ covered with epidermis-like layer $(e p)$ after six weeks culturing on $0.5 \mathrm{mg} / \mathrm{l} \mathrm{TDZ}$; parenchymatic cells $(p c)$ are visible. e Histological section of the basal part of the stem with root induction on $0.2 \mathrm{mg} / \mathrm{l} \mathrm{IAA}$; notice that the vascular tissues (arrows) of the root $(r)$ are connected with the vascular tissue of the stem (dashed line) surrounded by the callus (cal). Scale bars $=50 \mu \mathrm{m}(\mathbf{a 1}$, b1); $100 \mu \mathrm{m}$ (a, b); $200 \mu \mathrm{m}$ (c, e); $500 \mu \mathrm{m}$ (d)

- the genotype, and the source of explants (isolated from fresh fruits or year-old dry seeds) as important factors in establishing a successful plant regeneration system from the endosperm of $A$. arguta. Changing the concentration of PGRs in the culture medium and applying them individually or in combination can result either in direct or indirect organogenic developmental pathways (Feher 2019). Highly efficient callus induction and proliferation was observed from the isolated endosperm explants (obtained from fresh as well as dry seeds) of A. arguta in all tested cultivars on CIM and AEM. However, a morphogenic response occurred only on CIM. TDZ has been reported to be used in the successful regeneration of plants with different ploidy levels via endosperm-derived callus (Góralski et al. 2005; Popielarska 

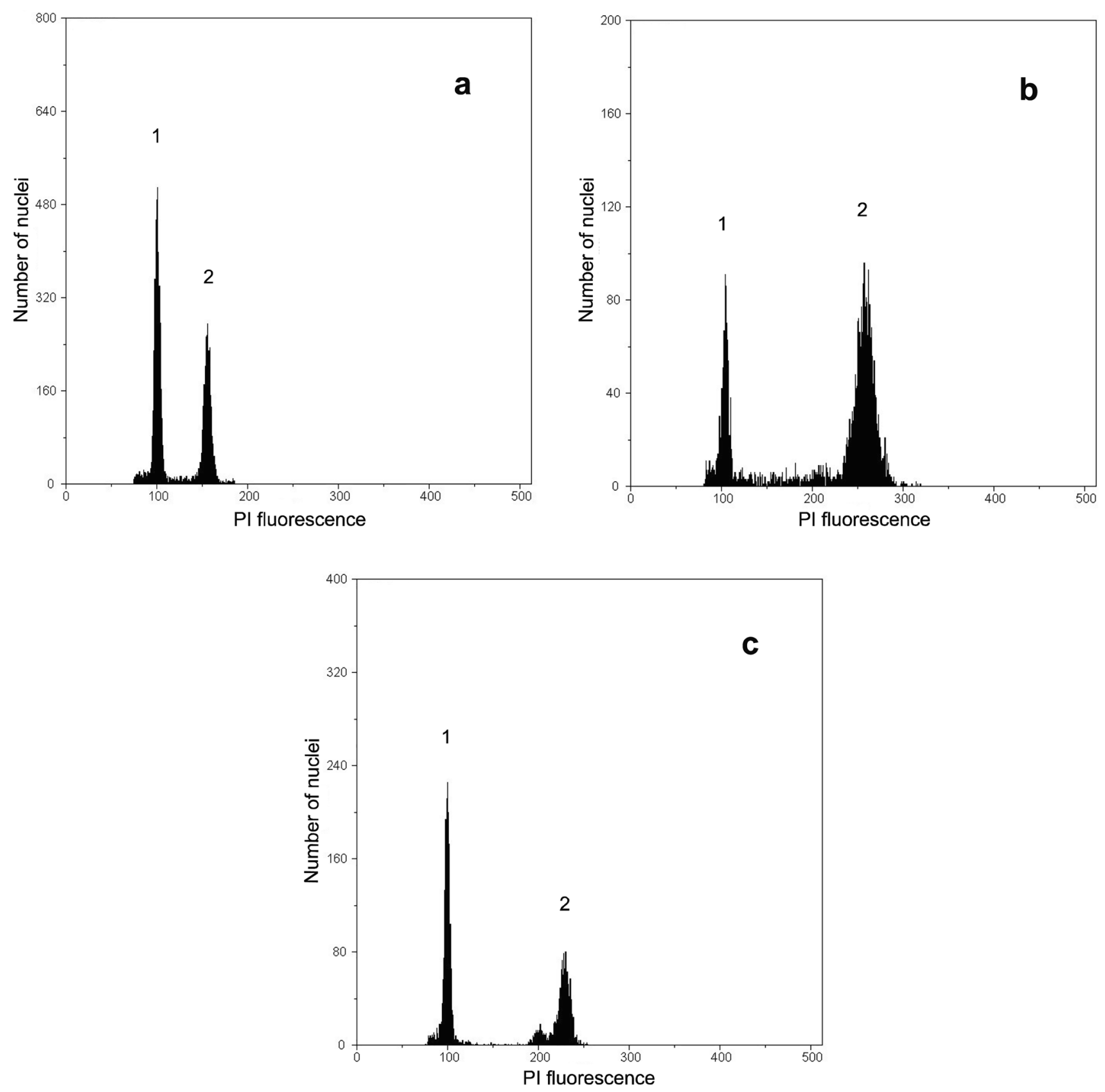

Fig. 3 FCM histograms of nuclear DNA content obtained after analysis of PI-stained nuclei isolated from leaves of Solanum lycopersicum (internal standard) and a leaf of tetraploid seedling of Actinidia arguta 'Bingo' $(2 \mathrm{C}=4 \mathrm{Cx}=3.1 \mathrm{pg}), \mathbf{b}$ hexaploid endosperm of $A$.

et al. 2006; Sun et al. 2011; Antoniazzi et al. 2018). TDZ is a phenlyurea compound that exhibits both auxin- and cytokinin-like properties and is more stable to withstand degradation by cytokinin oxidases (Mok et al. 1982). It also increases the accumulation of endogenous cytokinins and the translocation of auxins and it interacts synergistically with other culture media additives which induce shoot bud primordia (Murthy et al. 1998; Vinoth and Ravindhran arguta $(2 \mathrm{C}=6 \mathrm{Cx}=4.7 \mathrm{pg}), \mathbf{c}$ leaf of hexaploid endosperm-derived $A$. arguta regenerant $(2 \mathrm{C}=6 \mathrm{Cx}=4.5 \mathrm{pg})$. Peak 1: S. lycopersicum, peak 2: A. arguta

2018). Góralski et al. (2005) reported that A. deliciosa plants were regenerated from endosperm-derived callus on a medium supplemented with TDZ alone, during an extended period of subculturing. Similarly, TDZ was found to be the only cytokinin among all those tested that induced shoot production in endosperm explants from commercially grown passionfruit (Antoniazzi et al. 2018). On the contrary, in the present study, maintaining calli with adventitious shoot 
Table 4 Nuclear DNA content of Actinidia arguta 'Bingo' established in the isolated endosperm and leaves of nine seedlings grown in vitro (control) and leaves of 35 plants regenerated from endosperm-derived callus (15 from fresh seeds, and 20 from dry seeds, as a source of endosperm explants)

\begin{tabular}{|c|c|c|c|c|}
\hline \multirow[t]{2}{*}{ Plant material } & \multirow[t]{2}{*}{ No. of plants } & \multirow[t]{2}{*}{ DNA-ploidy } & \multicolumn{2}{|l|}{ DNA content (pg) } \\
\hline & & & $2 \mathrm{C}(\mathrm{SD})$ & $1 \mathrm{Cx}$ \\
\hline $\begin{array}{l}\text { Seedling (con- } \\
\text { trol) }\end{array}$ & 9 & $4 \mathrm{x}$ & $3.151(0.124)$ & 0.788 \\
\hline Endosperm & $4 *$ & $6 x$ & $4.755(0.047)^{* *}$ & 0.792 \\
\hline \multicolumn{5}{|c|}{ Source of endosperm explants } \\
\hline \multirow[t]{2}{*}{ Fresh seed } & 1 & $4 \mathrm{x}$ & 3.117 & 0.779 \\
\hline & 14 & $6 x$ & $4.497(0.035)$ & 0.750 \\
\hline \multirow[t]{2}{*}{ Dry seed } & 17 & $4 \mathrm{x}$ & $3.163(0.042)$ & 0.791 \\
\hline & 3 & $6 x$ & $4.527(0.033)$ & 0.754 \\
\hline
\end{tabular}

*Four samples, each containing 15-20 isolated endosperms

$* * 3 \mathrm{C}$ DNA content

primordia for a longer period on CIMs inhibited elongation and resulted in the formation of highly hyper-hydric leaflike structures. Our findings regarding the negative effects of TDZ on shoot elongation are in agreement with studies on Leucaena leucocephala, in which the authors reported an inverse relationship between TDZ and shoot elongation due to basal callusing, shoot fasciation, and necrosis (Shaik et al. 2009; Pal et al. 2012). The continuation of the shoots growth from the meristems could be the crucial problem during plant regeneration. The impact of the combination of many factors, like the media composition, light intensity, and $\mathrm{CO}_{2}$ concentration on the shoots quality is extensively analyzed for Actinidia (Infante et al. 1986; Hameg et al. 2020).

To overcome the problem of shoot elongation, it is recommended to transfer calli with adventitious shoot buds to a medium containing adenine-type cytokinins and auxins (Vinoth and Ravindhram 2018). In the present study, the microscopic shoot buds successfully elongated to a height of 1-3 cm when transferred from CIM to medium with ZEA or $m \mathrm{~T}$. ZEA, the first naturally occurring cytokinin to be identified, has been widely used in studies on plant tissue culture, and has already proven its organogenic potential in the genus Actinidia, in terms of adventitious shoot bud induction and elongation from callus cultures ( $\mathrm{Mu}$ et al. 1990; Liu et al. 1998; Takahashi et al. 2004; Lan et al. 2007). In A. kolomikta, shoot elongation was obtained only when an endosperm-derived callus with adventitious shoot primordia were cultured on ZEA (Asakura and Hoshino 2017). The successful use of ZEA for shoot regeneration was reported for Actinidia tissue after transformation or cryopreservation treatments (Wang et al. 2006; Mathew et al. 2018; Mathew et al. 2019; Herath et al. 2020; Pathirana et al. 2021). A novel derivative of the family of aromatic cytokinins, $m \mathrm{~T}$, has revealed promising results in plant organ culture studies (Jameson 2017), also for Actinidia taxon (Saeiahagh et al., 2019; Debenham and Pathirana 2021).

The induction of morphogenesis (like adventitious roots, shoot buds or somatic embryos formation) under in vitro culture, as well as in planta, is strongly related with stress factors, like PGRs, sucrose concentration, light intensity, and many others (Desjardins et al. 2009; Potters et al. 2009; Lieber 2019; Mahlanza et al. 2019). Anthocyanin production-one of the stress signals - in callus cultures is first characterized by the appearance of reddish-pink spots in the callus surface (Simões et al., 2012). The mechanical isolation and subcultures of the piece of callus forming these pigmented spots can lead to a significantly increase in pigment accumulation. Moreover, anthocyanins from the callus extract can show antioxidant and protective actions (Nazir et al. 2019). The report of Herath et al. (2020) pointed out that the anthocyanin accumulation could be desirable in Actinidia cultivation.

Regarding rooting, the micro-cuttings of $A$. arguta responded positively to different RIMs, though very minimal callus formation at the basal end of the stems occurred on a medium supplemented with IAA. On the contrary, robust rooting of micro-cuttings in A. deliciosa (Góralski et al. 2005) and A. kolomikta (Asakura and Hoshino 2017) was obtained on a half-strength-MS medium that was free of PGRs. The role of auxins, in turn, is well established in in vitro rooting of micro-cuttings and those hormones are widely used in plant species known to be recalcitrant to rooting (Fogaca and Fett-Neto 2005). In studies on endosperm culturing of Carica papaya (Sun et al. 2011) and Melia azedazach (Thang et al. 2018), more efficient rooting was reported when a small amount of auxins was added to the culture medium, which validates the findings of the current work.

\section{The role of the cultivar and the age of explant source}

Cultivars play an important role in establishing a successful plant regeneration system. A prominent cultivar effect was observed in the present study on A. arguta, especially in terms of the greater efficiency of explants producing calli with shoot buds in 'Bingo' in comparison to 'Scarlet September Kiwi', 'Geneva', and 'Weiki'. Many authors reported a highly cultivar-dependent response of explants cultured in vitro in different species (Jach and Przywara 2000; Scalzo et al. 2016; Farooq et al. 2017; Mostafa et al. 2020). In terms of callus size and subsequent plantlet regeneration of different cultivars of Vaccinium spp., $21 \%$ of the variation was attributed to cultivar (Scalzo et al. 2016). Also, a strong cultivar effect was observed during the propagation of olive (Farooq et al. 2017) and sunflower cultivars (Jach 
and Przywara 2000). Similarly, Mostafa et al. (2020) found significant differences between the rate of callus induction among four cultivars of garlic.

In the present study, culturing A. arguta endosperm isolated from year-old dry seeds resulted in plant regeneration, which may be of great significance due to the fact that fresh fruits are not available year-round. Similar studies on other species have yielded various results. Zhu et al. (1997) obtained regenerated plantlets from dry mature endosperm cultures of Eucommia ulmoides, but for Gomortega keule, the attempt to regenerate plantlets from the endosperm isolated from year-old dry seeds failed (Muñoz-Concha 2016). In the case of the genus Actinidia, no reports have been published to date on endosperm culturing from dry seeds. Our work demonstrates for the first time that the regeneration of complete plants with 3C DNA nuclear content from explants obtained from year-old dry seeds of A. arguta is possible - if not very efficient.

\section{Nuclear DNA content and DNA-ploidy}

Chromosome counting is a direct method to establish the ploidy of a plant. This approach can be very laborious and unreliable in A. arguta because of small size and relatively high number of chromosomes (>110) (Yan et al. 1997; Huang 2016; Bogačiovienè et al. 2019). On the other hand, FCM is a quick and reliable method of measuring nuclear DNA content in plants and DNA-ploidy can be calculated from the 2C value of a control plant with known ploidy (Bogačiovienè et al. 2019). FCM has been used extensively in estimating the genome size of horticultural and medicinal plants, especially in polyploid and hybrid breeding (Sliwinska 2018). The method has been used to confirm the endosperm origin of regenerated plants, for example, of A. chinensis var. deliciosa (Góralski et al. 2005), Gomortega keule (Muñoz-Concha 2016), A. kolomikta (Asakura and Hoshino 2017), Melia azedazach (Thang et al. 2018), and Passiflora cincinnata (Silva et al. 2020). For Actinidia, the range of DNA content of $2 \mathrm{C}$ nucleus for tetraploids was reported as 2.83-3.15 pg (an average $2.96 \mathrm{pg}$ ) (Start et al. 2007). Established here nuclear DNA content (about 3.1 $\mathrm{pg} / 2 \mathrm{C}$ ) was similar to that obtained previously for tetraploid A. arguta (3.10 pg/2C; Hopping 1994), which confirmed tetraploidy of studied in the present research cv. Bingo. The 3C DNA content established in the isolated endosperm was 4.75 pg $(1 \mathrm{Cx}=0.79 \mathrm{pg})$, and this value served as additional control to establish DNA-ploidy of regenerants from endospermderived calli. FCM analysis performed on A. arguta regenerants, obtained from both sources of explants, the endosperm from fresh and dry seeds, confirmed the hexaploidy $(6 \mathrm{Cx}=3 \mathrm{C}$ DNA content) of some the regenerants through a comparison with both the endosperm and the tetraploid seedlings of a commercially available tetraploid cultivar. However, a high proportion of desirable $6 \mathrm{Cx}$ plants were obtained only when fresh seeds were used as the source of explants. In our experience, isolating endosperm tissue is much easier using seeds from fresh fruits than dry seeds. That, in turn, makes it more likely, that some cells of the embryo, which adhere closely to the endosperm in dry seeds, can be included in the explant of the latter plant material. The $2 \mathrm{C}$ cells usually have a higher totipotency than those of higher ploidy (e.g. Kubaláková et al. 1996; Gilissen et al. 1994), and thus a higher proportion of tetraploid than hexaploid A. arguta plants were regenerated in this experiment. For this reason, when using dry seeds as a source of endosperm, estimating the ploidy of the regenerants is strongly recommended. Nevertheless, using endosperm explants from fresh seeds is rather suggested for a successful $6 \mathrm{Cx}$ plant regeneration of this species. However, because of the unavailability of fresh fruits of A. arguta all the year round, using endosperm explants from stored dry seeds seems to be an alternative.

When comparing the $1 \mathrm{Cx}$ values of tetraploid and hexaploid plants ( $0.79 \mathrm{pg}$ vs. $0.75 \mathrm{pg})$, a downsizing of the monoploid genome size is observed. This may be a result of aneuploidy as suggested by Chłosta et al. (2021).

\section{Ultrastructural and histological analyses}

Ultrastructural and histological analyses provide an opportunity to better understand and distinguish between different morphogenic events occurring under in vitro culture conditions (Haensch 2004; Kurczyńska et al. 2007; Dobrowolska et al. 2017). Most studies have reported plant regeneration via shoot bud formation from an endosperm-derived callus; in a few cases, somatic embryogenesis also occurred when endosperm explants were cultured (Hoshino et al. 2011). In A. arguta, the SEM and histological analyses of organogenic callus conducted as part of this study clearly depicted the induction of adventitious shoot buds from the endospermderived callus, followed by plant regeneration. The findings of this work are in agreement with previous microscopic observations carried out on an isolated endosperm culture in the Actinidia taxon (Góralski et al. 2005; Asakura and Hoshino 2017). In those studies, the dedifferentiation of storage tissue to parenchymatic callus was clearly visible. Other studies have reported the adventitious nature of shoot bud formation in an endosperm-derived callus (Popielarska et al. 2006; Popielarska-Konieczna et al. 2020; Czernicka et al. 2021).

\section{Conclusions}

In conclusion, we have demonstrated for the first time that the isolated endosperm of kiwiberry, A. arguta, could be successfully used as an explant for callus proliferation. A full protocol of plant regeneration from endosperm of cultivar 
'Bingo' and the acclimatization of regenerants has been developed. The type of tetraploid cultivar $(2 \mathrm{C}=4 \mathrm{Cx})$ and the source of explants (fresh vs. year-old dry seeds) affected the regeneration ability. The genome size of tetraploids of $A$. arguta was established as $3.1 \mathrm{pg} / 2 \mathrm{C}$ and of hexaploids 4.5 $\mathrm{pg} / 2 \mathrm{C}$. Because of the probability of regenerating undesirable tetraploid plants, seeds isolated from fresh fruit than dry seeds should be used as a source of endosperm, if possible. Nevertheless, in all cases the ploidy of the regenerants should be established because of the probability of obtaining $4 \mathrm{Cx}$ plants, regenerated from the remnant of the embryo. The present findings are valuable because hexaploid plants can be an important source of breeding material for further improvement of kiwiberry germplasm. Moreover, future studies using media with varying concentrations of ZEA and/or $m \mathrm{~T}$ could help to induce the adventitious shoot formation from endosperm-derived callus in recalcitrant genotypes, like 'Geneva' and 'Weiki'.

Author contributions MPK devised the research. MA, MT, and PW performed the tissue cultures. MA and MPK performed the histological and SEM studies. MA and PL visualized the results. ES carried out the flow cytometry analysis and evaluated the results. GG carried out the statistical analysis. MA, ES, and MPK contributed to the writing of the manuscript. All of the authors read and approved the final manuscript.

Funding This work was financially supported from the statutory activities (K/ZDS/008057) of the Institute of Botany, from statutory activity funds for the development of PhD students in 2019 and 2020 at the Faculty of Biology at the Jagiellonian University in Krakow, and the statutory activities (BN-34/2019) of the Faculty of Agriculture and Biotechnology at the UTP University of Science and Technology in Bydgoszcz.

Data availability The data generated and/or analyzed during the current study are available from the corresponding author upon reasonable request.

\section{Declarations}

Conflict of interest The authors declare that they have no conflicts of interest.

Open Access This article is licensed under a Creative Commons Attribution 4.0 International License, which permits use, sharing, adaptation, distribution and reproduction in any medium or format, as long as you give appropriate credit to the original author(s) and the source, provide a link to the Creative Commons licence, and indicate if changes were made. The images or other third party material in this article are included in the article's Creative Commons licence, unless indicated otherwise in a credit line to the material. If material is not included in the article's Creative Commons licence and your intended use is not permitted by statutory regulation or exceeds the permitted use, you will need to obtain permission directly from the copyright holder. To view a copy of this licence, visit http://creativecommons.org/licenses/by/4.0/.

\section{References}

Antoniazzi CA, Faria RB, Carvalho PP, Mikovski AI, Carvalho IF, Matos EM, Reis AC, Viccini LF, Pinto DLP, Rocha DI, Otoni WC, Silva ML (2018) In vitro regeneration of triploid plants from mature endosperm culture of commercial passionfruit (Passiflora edulis Sims). Sci Hortic 238:408-415. https://doi.org/10.1016/j. scienta.2018.05.001

Asakura I, Hoshino Y (2017) Endosperm-derived triploid plant regeneration in diploid Actinidia kolomikta, a cold-hardy kiwifruit relative. Sci Hortic 219:53-59. https://doi.org/10.1016/j.scienta.2017. 02.045

Bogačiovienė S, Cesonienè L, Ercisli S, Valatavicius A, Jakstys B, Satkauskas S, Paulauskas A (2019) Ploidy levels and genetic diversity of Actinidia arguta (Siebold \& Zucc.) Planch. ex Miq, A. kolomikta (Rupr. \& Maxim.) Maxim, A. callosa Lindl, and A. melanandra Franch, accessions. Genet Resour Crop Evol 66:1107-1118. https://doi.org/10.1007/s10722-019-00775-9

Cossio F, Debersaques F, Latocha P (2015) Kiwiberry (Actinidia arguta): new perspectives for a great future. Acta Hortic 1096:423-434. https://doi.org/10.17660/ActaHortic.2015.1096.51

Chłosta I, Kwolek D, Sliwinska E, Góralski G, Popielarska-Konieczna M (2021) Sex-linked molecular markers identify female lines in endosperm-derived kiwifruit callus and in regenerants. Plants 10:526. https://doi.org/10.3390/plants10030526

Czernicka M, Chłosta I, Kęska K, Kozieradzka-Kiszkurno M, Abdullah M, Popielarska-Konieczna M (2021) Protuberances are organized distinct regions of long-term callus: histological and transcriptomic analyses in kiwifruit. Plant Cell Rep 40:637-665. https:// doi.org/10.1007/s00299-021-02661-0

Debenham M, Pathirana R (2021) Establishment and management of an in vitro repository of kiwifruit (Actinidia ssp.) germplasm. In: Ahmad N, Strnad M (eds) Meta-topolin: a growth regulator for plant biotechnology and agriculture. Springer Nature, Singapore. https://doi.org/10.1007/978-981-15-9046-7_20

Debersaques F, Mekers O, Decorte J, Van Labeke MC, SchoedlHummel K, Latocha P (2015) Challenges faced by commercial kiwiberry (Actinidia arguta Planch.) production. Acta Hortic 1096:435-442

Desjardins Y, Dubuc JF, Badr A (2009) In vitro culture of plants: a stressful activity! Acta Hortic 812:29-50

Dobrowolska I, Andrade GM, Clapham D, Egertsdotter U (2017) Histological analysis reveals the formation of shoots rather than embryos in regenerating cultures of Eucalyptus globulus. Plant Cell Tissue Organ Cult 128:319-326.

Doležel J, Sgorbati S, Lucretti S (1992) Comparison of three DNA fluorochromes for flow cytometric estimation of nuclear DNA content in plants. Physiol Plant 85:625-631. https://doi.org/10. 1111/j.1399-3054.1992.tb04764.x

Farooq QUA, Fatima A, Murtaza N, Hussain FF (2017) In vitro propagation of olive cultivars 'Frontio', 'Earlik', 'Gemlik'. Acta Hortic 1152:249-256. https://doi.org/10.17660/ActaHortic.2017.1152.34

Feher A (2019) Callus, dedifferentiation, totipotency, somatic embryogenesis: what these terms mean in the era of molecular plant biology? Front Plant Sci 10:536. https://doi.org/10.3389/fpls.2019. 00536

Ferguson AR (2016) Botanical description. In: Testolin R, Huang HW, Ferguson A (eds) The kiwifruit genome. Compendium of plant genomes. Springer International Publishing, New York. https:// doi.org/10.1007/978-3-319-32274-2

Ferguson AR, Huang H (2007) Genetic resources of kiwifruit: domestication and breeding. In: Janick J (ed) Horticultural reviews. John Wiley and Sons, Inc, New Jersy. https://doi.org/10.1002/97804 70168011.ch1 
Fogaca CM, Fett-Neto AG (2005) Role of auxin and its modulators in the adventitious rooting of Eucalyptus species differing in recalcitrance. Plant Growth Regul 45(1):1-10

Gilissen LJW, Staveren MJV, Hakkert JC, Smulders MJM, Verhoeven HA, Creemers-Molenaar J (1994) The competence of cells for cell division and regeneration in tobacco explants depends on cellular location, cell cycle phase and ploidy level. Plant Sci 103(1):8991. https://doi.org/10.1016/0168-9452(94)03976-3

Góralski G, Popielarska M, Ślesak H, Siwińska D, Batycka M (2005) Organogenesis in endosperm of Actinidia deliciosa cv. Hayward cultured in vitro. Acta Biol Crac Ser Bot 47:121-128

Greilhuber J, Doležel J, Lysák MA, Bennett MD (2005) The origin, evolution and proposed stabilization of the terms 'genome size' and 'C-value' to describe nuclear DNA contents. Ann Bot 95(1):255-260

Gui YL, Mu XJ, Xu TY (1982) Studies on morphological differentiation of endosperm plantlets of Chinese gooseberry in vitro. Acta Bot Sin 24:216-221

Haensch K-T (2004) Morpho-histological study of somatic embryolike structures in hypocotyl cultures of Pelargonium $\times$ hortorum Bailey. Plant Cell Rep 22:376-381. https://doi.org/10.1007/ s00299-003-0726-2

Hameg R, Arteta TA, Landin M, Gallego PP, Barreal ME (2020) Modeling and optimizing culture medium mineral composition for in vitro propagation of Actinidia arguta. Front Plant Sci 11:554905. https://doi.org/10.3389/fpls.2020.554905

Herath D, Wang T, Peng Y, Allan AC, Putterill J, Varkonyi-Gasic E (2020) An improved method for transformation of Actinidia arguta utilized to demonstrate a central role for MYB110 in regulating anthocyanin accumulation in kiwiberry. Plant Cell Tissue Org Cult 43:291-301. https://doi.org/10.1007/s11240-020-01915-1

Hopping ME (1994) Flow cytometric analysis of Actinidia species. N Z J Bot 32:85-93

Hoshino H, Miyashita T, Thomas TD (2011) In vitro culture of endosperm and its application in plant breeding: approaches to polyploidy breeding. Sci Hortic 130:1-8. https://doi.org/10. 1016/j.scienta.2011.06.041

Huang H (2016) Kiwifruit: the genus ACTINIDIA. Elsevier Inc., Amsterdam. https://doi.org/10.1016/B978-0-12-803066-0. 09999-8

Infante R, Magnanini E, Righetti B (1986) The role of light and $\mathrm{CO}_{2}$ in optimizing the conditions for shoot proliferation of Actinidia deliciosa in vitro. Physiol Plant 77:191-195. https://doi.org/10. 1111/j.1399-3054.1989.tb04968.x

Jach M, Przywara L (2000) Somatic embryogenesis and organogenesis induced on the immature zygotic embryos of Helianthus annuus L. - the role of genotype. Acta Biol Crac Ser Bot 42(2):83-86

Jameson PE (2017) Cytokinins. In: Thomas B, Murry BG, Murphy D (eds) Encyclopedia of applied plant sciences, 2nd edn. Elsevier Ltd, Amsterdam, pp 391-402

Kubaláková M, Doležel J, Lebeda A (1996) Ploidy instability of embryogenic cucumber (Cucumis sativus L.) callus culture. Biol Plant 38(3):475-480. https://doi.org/10.1007/BF02896685

Kumar A, Gupta N (2015) Applications of triploids in agriculture. In: Bahadur B, Rajam MV, Shahijram L, Krishnamurthy KV (eds) Plant biology and biotechnology: volume II: plant genomics and biotechnology. Springer, India, pp 385-396

Kurczyńska EU, Gaj MD, Ujczak A, Mazur E (2007) Histological analysis of direct somatic embryogenesis in Arabidopsis thaliana (L.) Heynh. Planta 226:619-628. https://doi.org/10.1007/ s00425-007-0510-6

Lan DW, Liu YL, Harada T (2007) Organogenesis, somatic embryogenesis and plantlet regeneration from leaf explants of Actinidia kolomikta cultured in vitro. J Fruit Sci 24:218-221
Latocha P (2017) The nutritional and health benefits of kiwiberry (Actinidia arguta) - a review. Plant Foods Hum Nutr 72:325-334. https://doi.org/10.1007/s11130-017-0637-y

Li M, Ma F, Liang D, Li J, Wang Y (2010) Ascorbate biosynthesis during early fruit development is the main reason for its accumulation in kiwi. PloS One 5(12):e14281. https://doi.org/10.1371/journal. pone.0014281

Lieber MM (2019) The induction and maintenance of in vitro plant morphogenesis as viewed from a new perspective, with theoretical and constructive implications. Biosystems 184:103994. https:// doi.org/10.1016/j.biosystems.2019.103994

Liu YL, Masuda K, Harada T (1998) Plantlet regeneration, organ formation and somatic embryogenesis from in vitro-cultured root tissue of Actinidia kolomikta. J Japan Soc Hortic Sci 67:734-738. https://doi.org/10.2503/jjshs.67.734 (In Japanese with English abstract).

Machno D, Przywara L (1997) Endosperm culture of Actinidia species. Acta Biol Crac Ser Bot 39(1):56-61

Mahlanza T, Rutherford RS, Snyman SJ, Watt MP (2019) Methylglyoxal-induced enhancement of somatic embryogenesis and associated metabolic changes in sugarcane (Saccharum spp. hybrids). Plant Cell Tissue Org Cult 136:279-287. https://doi. org/10.1007/s11240-018-1513-7

Mathew L, McLachlan A, Jibran R, Burritt DJ, Pathirana R (2018) Cold, antioxidant and osmotic pre-treatments maintain the structural integrity of meristematic cells and improve plant regeneration in cryopreserved kiwifruit shoot tips. Protoplasma 255:1065-1077. https://doi.org/10.1007/s00709-018-1215-3

Mathew L, Burritt DJ, McLachlan A, Pathirana R (2019) Combined pre-treatments enhance antioxidant metabolism and improve survival of cryopreserved kiwifruit shoot tips. Plant Cell Tissue Org Cult 138:193-205. https://doi.org/10.1007/ s11240-019-01617-3

Melo ATO, Guthrie RS, Hale I (2017) GBS-deconvolution of the surviving North American of cold-hardy kiwifruit (Actinidia ssp.) germplasm. PLoS One 12(1):e0170580

Mok MC, Mok DWS, Armstrong DJ, Shudo K, Isogai Y, Okamoto T (1982) Cytokinin activity of N-phenyl-N'-1, 2,3-thiadiazol-5-ylurea (thidiazuron). Phytochemistry 21(7):1509-1511. https://doi. org/10.1016/S0031-9422(82)85007-3

Mostafa HHA, Wang H, Song J, Li X (2020) Effects of genotypes and explants on garlic callus production and endogenous hormones. Sci Rep 10:4867. https://doi.org/10.1038/s41598-020-61564-4

Mu SK, Fraser LG, Harvey CF (1990) Initiation of callus and regeneration of plantlets from endosperm of Actinidia interspecific hybrids. Sci Hortic 44:107-117. https://doi.org/10.1016/03044238(90)90021-6

Muñoz-Concha D (2016) Culture of triploid tissue from the endosperm of an endangered Chilean tree species Gomortega keule. J Hortic Sci Biotech 91(1):79-86. https://doi.org/10.1080/14620316.2015. 1110995

Murashige T, Skoog F (1962) A revised medium for rapid growth and bioassay with tobacco tissue cultures. Physiol Plantarum 15:473497. https://doi.org/10.1111/j.1399-3054.1962.tb08052.x

Murthy BNS, Murch S, Saxena P (1998) Thidiazuron: a potent regulator of in vitro plant morphogenesis. In Vitro Cell Dev Biol Plant 34:267-275

Nazir M, Tungmunnithum D, Bose S, Drouet S, Garros L, GiglioliGuivarch N, Abbasi BH, Hano C (2019) Differential production of phenylpropanoid metabolites in callus cultures of Ocimum basilicum $\mathrm{L}$. with distinct in vitro antioxidant activities and in vivo protective effects against UV stress. J Agric Food Chem 67(7):1847-1859. https://doi.org/10.1021/acs.jafc.8b05647

Pal A, Negi VS, Borthakur D (2012) Efficient in vitro regeneration of Leucaena leucocephala using immature zygotic embryos as 
explants. Agroforest Syst 84:131-140. https://doi.org/10.1007/ s10457-011-9438-8

Pathirana R, Mathew L, McLachlan A (2021) A simplified method for high recovery of kiwifruit (Actinidia spp.) shoot tips after droplet vitrification cryopreservation suitable for long-term conservation. Plant Cell Tissue Org Cult 144:97-102. https://doi.org/10.1007/ s11240-020-01860-z

Popielarska M, Ślesak H, Góralski G (2006) Histological and SEM studies on organogenesis in endosperm-derived callus of kiwifruit (Actinidia deliciosa cv. Hayward). Acta Biol Cracov Bot 48(2):97-104

Popielarska-Konieczna M, Sala K, Abdullah M, Tuleja M, Kurczyńska (2020) Extracellular matrix and wall composition are diverse in organogenic and nonorganogenic calli of Actinidia arguta. Plant Cell Rep 39:779-798. https://doi.org/10.1007/ s00299-020-02530-2

Potters G, Pasternak TP, Guisez Y, Jansen AKM (2009) Different stresses, similar morphogenic responses: integrating a plethora of pathways. Plant Cell Environ 32:158-169. https://doi.org/10. 1111/j.1365-3040.2008.01908.x

R Core Team (2020) R: a language and environment for statistical computing. R Foundation for Statistical Computing, Vienna

Saeiahagh H, Mousavi M, Wiedo C, Bassett HB, Pathirana R (2019) Effect of cytokinins and sucrose concentration on the efficiency of micropropagation of 'Zes006' Actinidia chinensis var chinensis, a redflesh kiwifruit cultivar. Plant Cell Tissue Org Cult 138:1-10. https://doi.org/10.1007/s11240-019-01597-4

Scalzo J, Donno D, Miller S, Ghezzi M, Mellano MG, Cerutti AK, Beccaro GL (2016) Effect of genotype, medium and light on in vitro plant proliferation of Vaccinium spp. N Z J Crop Hort 44(4):231-246. https://doi.org/10.1080/01140671.2016.1206946

Shaik NM, Arha M, Nookaraju A, Gupta SK, Srivastava S, Yadav AK, Kulkarni PS, Abhilash OU, Vishwakarma RK, Singh S, Tatkare R, Chinnathambi K, Rawal SK, Khan BM (2009) Improved method of in vitro regeneration in Leucaena leucocephala - a leguminous pulpwood tree species. Physiol Mol Biol Plant 15:311-318. https://doi.org/10.1007/s12298-009-0035-5

Silva NTD, Silva LAS, Reis AC, Machado M, Matos EMD, Viccini LF, Otoni WC, Carvalho IFD, Rocha DI, Silva MLD (2020) Endosperm culture: a facile and efficient biotechnological tool to generate passion fruit (Passiflora cincinnata Mast.) triploid plants. Plant Cell Tissue Org Cult 142:613-624. https://doi.org/10.1007/ s11240-020-01887-2

Simões C, Albarello O, De Castro TC, Mansur E (2012) Production of anthocyanins by plant cell and tissue culture strategies. In: Orhan IE (ed) Biotechnological production of plant secondary metabolites. Bentham Science Publishers, Sharjah

Sliwinska E (2018) Flow cytometry - a modern method for exploring genome size and nuclear DNA synthesis in horticultural and medicinal plant species. Folia Hort 30(1):103-128
Sliwinska E, Thiem B (2007) Genome size stability in six medicinal plant species propagated in vitro. Biol Plant 51:556-558. https:// doi.org/10.1007/s10535-007-0121-x

Start MA, Luby J, Filler D, Riera-Lizarazu O, Guthrie R (2007) Ploidy level of cold-hardy Actinidia accessions in the United States determined by flow cytometry. Acta Hortic 753:161-168. https://doi. org/10.17660/ActaHortic.2007.753.17

Sun DQ, Lu XH, Gu L, Guo QG, Mo YW, Xie JH (2011) Production of triploid plants of papaya by endosperm culture. Plant Cell Tissue Organ Cult 104:23-29. https://doi.org/10.1007/ s11240-010-9795-4

Takahashi W, Sugawara F, Yamamoto, Bando E, Matsushita J, Tanaka S (2004) Plant regeneration in Actinidia polygama Miq. by leaf, stem, and petiole culture with zeatin, and from stem-derived calli on low-sucrose medium. J For Res 9:85-88. https://doi.org/10. 1007/s10310-003-0053-Z

Thang BV, Viet NV, Nam VQ, Tung HT, Nhut DT (2018) Triploid plant regeneration from immature endosperms of Melia azedazach. Plant Cell Tissue Org Cult 133:351-357. https://doi.org/10.1007/ s11240-018-1387-8

Vinoth A, Ravindhran R (2018) In vitro morphogenesis of woody plants using thidiazuron. In: Ahmad N, Faisal M (eds) Thidiazuron: from urea derivative to plant growth regulator. Springer Nature Singapore Pte Ltd, Singapore, pp 231-246

Wang T, Ran Y, Atkinson RG, Gleave AP, Cohen D (2006) Transformation of Actinidia eriantha: a potential species for functional genomics studies in Actinidia. Plant Cell Rep 25:425-431. https:// doi.org/10.1007/s00299-005-0080-7

Wang X, Cheng Z-M, Zhi S, Xu F (2016) Breeding triploid plants: a review. Czech J Genet Plant 52:41-54. https://doi.org/10.17221/ 151/2015-CJGPB

Wu RM, Walton EF, Richardson AC, Wood M, Hellens RP, VarkonyiGasic E (2012) Conservation and divergence of four kiwifruit SVP-like MADS-box genes suggest distinct roles in kiwifruit bud dormancy and flowering. J Exp Bot 63(2):797-807. https://doi. org/10.1093/jxb/err304

Yan G, Yao Y, Ferguson AR, McNeilage MA, Seal AG, Murray BG (1997) New reports of chromosome numbers in Actinidia (Actinidiaceae). N Z J Bot 35:181-186. https://doi.org/10.1080/00288 25X.1997.10414154

Zhu D, Jiang J, Pei D, Tian H, Wang M, Zhu M, Mi J, Li J (1997) Plant regeneration from dry mature endosperm cultures of Eucommia ulmoides Oliv. Chin Sci Bull 42:703-704

Publisher's Note Springer Nature remains neutral with regard to jurisdictional claims in published maps and institutional affiliations. 